Maria Groenwald

https://doi.org/10.26881/pwe.2020.48.01

ORCID: 0000-0003-3771-7286

Uniwersytet Gdański

maria.groenwald@ug.edu.pl

\title{
Czas w uczeniu się. Analiza krytyczna perspektywy obiektywistycznej
}

\section{Summary}

\section{Time in learning. Critical analysis of the objectivist perspective}

The paper is a critical analysis of time in learning, functioning in the objectivist approach to education. Referring to results of anthropological research and literary studies in this field, I justify in it the thesis that in transmissive teaching becomes an instrument for subjugating children. It is supported by the following realities of schooling: imposed time of children's stay at school, an obligation to do homework and timeframe of "covering" textbooks, which leads to pupils being overloaded with school learning, wasting time at lessons, repeating years, or even being halted in time. The effect of the time of learning being seized by the time of teaching is petrification of the bureaucratic management of time, pretended learning and tabooism of the disturbing phenomenon of the temporary regime of learning.

Keywords: time as a category of learning, objectivist category of learning, subjugation of learners, school, critical analysis

Słowa kluczowe: czas jako kategoria uczenia się, obiektywistyczny paradygmat uczenia się, zniewolenie uczących się, szkoła, analiza krytyczna

Czas w dydaktyce $\mathrm{z}$ reguły jest traktowany bezrefleksyjnie i najczęściej fizykalnie, zamyka się go w wymiarze: trwającej 45 minut lekcji, semestru, roku szkolnego. To czas mierzalny i znormalizowany, który umożliwia przypisanie każdemu zdarzeniu liczby oznaczającej jego zaistnienie, wyznaczone początkiem lub końcem, okresem trwania bądź aktualną godziną odczytu z zegarka (Hawking 2015: 225; Bierdiajew 2003: 184-189). Ale patrząc na ów czas przez pryzmat czynności nauczyciela i uczniów na lekcji czy analizując zindywidualizowane doświadczanie go przez uczestników kształcenia, dostrzega się, że jest on także konstrukcją społeczną - elementem (wielo)czasu rozumianego jako jednoczesność dziania się czasów: zegarowego, społecznego i przeżywanego (Urry 2009; Szadura 2017: 81). W niniejszym opracowaniu na pierwszym planie znalazł się czas społeczny, egzystencjalny, z jednej strony bardzo wyraźnie uobecniający się w procesie kształcenia, z drugiej zaś - będący w dydaktyce kategorią nieobecną i pomijaną. Tymczasem brak refleksyjnego podejścia do czasu i traktowanie go jako narzędzia w pracy z uczniem skutkuje poważnymi konsekwencjami. 
W analizie skorzystam z wyników badań przeprowadzonych poza obszarem dydaktyki, czerpiąc (najogólniej) z antropologii, w ramach której prowadzone są rozważania o temporalnym uwikłaniu człowieka. Umożliwiają one podjęcie refleksji nad czasem w uczeniu się i nauczaniu. Nie sposób jednak nie dostrzec jego zróżnicowanego statusu sygnalizowanego przez teorię kształcenia, umożliwiającą odczytanie go przez pryzmat odmiennych założeń paradygmatycznych (ontologiczno-epistemologicznych i aksjologicznych), leżących u podstaw paradygmatów dydaktyki: obiektywistycznego, konstruktywistyczno-interpretatywnego oraz transformatywnego (Klus-Stańska 2018). W związku z tym, że w polskich szkołach wciąż jeszcze dominuje kształcenie normatywne $\mathrm{i}$ instrukcyjne, wpisane w paradygmat obiektywistyczny, w niniejszym tekście skupiłam się na uzasadnieniu tezy o traktowaniu czasu w nauczaniu jako instrumentu opresji i zniewalania dzieci.

\section{Czas w kształceniu transmisyjnym - czy sprzyja uczeniu się}

Już w momencie narodzin dziecku zostaje przypisana godzina pojawienia się na świecie początkowy moment jego życia, jeden z pierwszych znaczników, który zawsze będzie mu towarzyszył. W kolejnych latach dzieciństwa czas również jest obecny, ponieważ ustanawia się godziny posiłków, spacerów, odpoczynku itd. „Już czas” - te słowa dziecko słyszy wówczas, gdy ma kończyć zabawę, przygotować się do snu. W tych sytuacjach „czas” staje się niepodważalnym argumentem, z którym nie sposób dyskutować. A potem idzie do szkoły...

Teraz ramy czasowe wyznaczające rytm życia dziecka stają się bardziej restrykcyjne. Trzeba wcześnie wstać, choć - jak wynika z badań naukowców z Kanady i ze Stanów Zjednoczonych - wczesne wstawanie jest dla dzieci i młodzieży niekorzystne, ponieważ niewysypianie się prowadzi m.in. do większej podatności na depresję, stany lękowe, stwarzanie problemów wychowawczych, a dodatkowo sprzyja osiąganiu gorszych wyników w szkole, natomiast rozpoczynanie lekcji o 8.30 okazuje się znacząco lepsze dla uczniów (za: Dzieliński 2017a, 2017b). Niestety, tych doniesień nie uwzględnia się w temporalnej organizacji życia szkoły i lekcje nadal rozpoczynają się o ósmej, choć niektóre dzieci pojawiają się w niej jeszcze wcześniej, oczekując na zajęcia w świetlicy.

Dzwonki na lekcje i przerwy wyznaczają rytm dnia i nawet jeśli nie dotyczą uczniów klas 1-3, to często są przez nich słyszane. Na razie stanowią kontekst dziecięcej codzienności oraz zapowiedź nieodległej przyszłości, w której będą obecne. Ich dźwięk rozdzielać będzie dwie jakościowo różne rzeczywistości: przerwę - czas odpoczynku, swobody, zgiełku, od lekcji - czasu pracy, zdyscyplinowania i uczniowskiego milczenia sporadycznie przerywanego, wyłącznie za zgodą nauczyciela, zabraniem głosu poprzedzonym podniesieniem ręki (Martyniuk 2012).

Analiza czasu prowadzona z perspektywy paradygmatu obiektywistycznego uświadamia, że kiedy kształceniem zarządza czas, wówczas znaczącą rolę odgrywa w nim planowanie. Jest ono konsekwencją temporalności wpisanej w podstawę programową, która 
przewiduje, jakie wiadomości i umiejętności uczniowie powinni opanować w kolejnych latach pobytu w szkole. Tym samym przed nauczającym pojawia się zadanie należytego zaplanowania im uczenia się w tak założonym przedziale czasowym (roku, semestru, miesiąca itd.), by zdążyli spełnić wymagania programowe. Nauczyciel dokonuje tego, prowadząc kilka rodzajów planowania: a) kierunkowe - obejmujące rok, semestr, rozdział z podręcznika; b) wynikowe - wskazujące, które partie materiału uczeń ma przyswoić w danym przedziale czasu; c) metodyczne - sporządzany jest konspekt lub scenariusz zajęć; zatem przewiduje się w nim, jak nauczyciel i uczniowie będą pracowali na danej lekcji (Gagnè i in. 1992: 17-18; Niemierko 1995: 370).

Przebieg lekcji pozostaje w ścisłym związku z tymi planami, ale też z podstawą programową, podręcznikiem i przewodnikiem metodycznym nauczyciela - napisanymi z wyprzedzeniem (czasem kilkuletnim), a więc na długo przed tym, zanim uczniowie zasiądą w szkolnych ławkach. Kolejnym krokiem jest dopuszczenie materiałów dydaktycznych do użytku szkolnego przez ministerstwo oraz ministerialnych recenzentów. Należy żałować, że w formułowanych opiniach nie uwzględniają ich adekwatności do potrzeb i zainteresowań dzieci oraz ograniczają elastyczność kształcenia apriorycznością założeń odnośnie do ,przerabianych” treści i czasu ich realizacji. Mimo tego mankamentu niestety przez kolejne lata będą wyznaczać i nauczycielom, i uczniom jedynie słuszną - bo akceptowalną w biurokratycznie sterowanej edukacji - drogę nauczania i uczenia się. Przebiega ona według modelu, w którym: a) nauczycielskie nauczanie zdecydowanie dominuje nad uczniowskim uczeniem się; b) preferowana jest transmisyjność kształcenia, oznaczająca kultywowanie nauczania wyprowadzonego z przeszłości; c) nauczanie podlega temporalnej inercji (,tak było kiedyś, tak powinno być nadal”); d) powszechne jest przyzwolenie na zarządzanie kształceniem przez czas, określane „dominacją kultury zegara” (Korzeniecka-Bondar 2018: 251). Zgoda na podporządkowanie się władzy czasu przenika codzienne wypowiedzi nauczycieli i uczniów w zwrotach: „czas się wlecze, biegnie, ucieka, płynie, leci, przemija” (Wiśniewska-Kin 2013: 301). To czas, który zarządza ich działaniem, nadaje mu tempo, wyznacza nieprzekraczalne granice. Z perspektywy konstruktywistycznej takie działanie niepokoi, gdyż uczący się zostają sprowadzeni do roli jednorodnej masy, której obowiązkiem jest przyswajanie w jednakowym tempie takich samych „porcji” wiedzy. Brakuje w nim samodzielności uczenia się i czerpania radości z dokonywanych przez dzieci odkryć.

Po zakończeniu zajęć w szkole następuje powrót do domu i odrabianie lekcji. Część czasu przeznaczonego na odpoczynek zostaje skrócony przez pracę domową, trwającą o wiele dłużej, niż przewidują to normy zdrowotne, co oznacza, że pojawia się przeciążenie nauką pozaszkolną. Dochodzi do niego wówczas, gdy wymagania stawiane uczniowi znacznie przerastają jego możliwości, a czas przeznaczony na pracę domową przekracza przewidywaną normę. Największe odchylenia od higienicznej normy czasowej domowego uczenia się dotyczą pierwszoklasistów, którzy codziennie przekraczają ją o 50 minut, czyli łączne dzienne obciążenie pracą domową sięga około 80 minut. Zbliżony jest czas codziennego domowego uczenia się drugoklasistów - 78 minut oraz 
trzecioklasistów - 73 minuty. Z badań wynika również, że najbardziej przeciążone nauką domową są dzieci bardziej wykształconych rodziców, którzy posyłają je na dodatkowe lekcje języków obcych (głównie angielskiego) albo na takie zajęcia pozaszkolne, jak: nauka muzyki, tańca, jazdy konnej bądź zajęcia sportowe (Kruszko 2006: 40-46, 105). Ponadto uczniowie uczęszczają na korepetycje (Bray 2012: 23-24).

Z jednej strony zajęcia pozalekcyjne umożliwiają wyrównywanie wiedzy i umiejętności odbiegających od szkolnych wymogów, sprzyjają również rozwijaniu dziecięcych zainteresowań, z drugiej zaś są świadectwem obojętności szkoły (nauczycieli) na potrzeby i możliwości edukacyjne uczniów, na ich pasje oraz talenty. O obojętności można mówić wówczas, gdy mimo uświadamiania sobie przez nauczyciela indywidualnych potrzeb dziecka w uczeniu się postanawia on przyjąć - krytykowaną przez Jacka Filka (2001: 164) - strategię „nicnierobienia”, tym bardziej że bezczynności towarzyszy samousprawiedliwiające tłumaczenie, polegające na wskazywaniu źródła trudności poza nauczycielem, i twierdzenie, że „samo sobie jest winne”, co sugeruje, że sprawcą niepowodzeń jest dziecko. Wykazuje też skłonność do zrzucania odpowiedzialności za te niepowodzenia na jeszcze innych winowajców, takich jak: system oświaty, ministerialne rozporządzenia traktowane jako jedyna wykładnia pracy z uczniem oraz uprawomocnienie lekceważącego stosunku wobec dziecka, w tym przymuszanie go do wydłużonego czasu uczenia się poza szkołą.

Konsekwencje obojętności na przeciążenie uczeniem się są dla uczących się dramatyczne i długofalowe. Zaledwie zasygnalizuję kilka z nich - są to m.in.: marnowanie czasu, powtarzanie go czy zatrzymywanie w nim dziecka. Przede wszystkim w zorientowanym obiektywistycznie kształceniu, ale też w programie oraz w planowaniu uczeń jest pomijany jako osoba. Owszem, pojawia się w nich, choć jako zaledwie element umożliwiający realizację założeń edukacyjnych, a te są niepodważalne. Jeśli na przykład zdarzy się, że dziecko już potrafi czytać - chociaż według programu nie powinno tego umieć - w normatywnie ukierunkowanym nauczaniu ,równym frontem” poczeka na kolegów, aż ci opanują wymaganą umiejętność. Zatrzymanie go w procesie uczenia się będzie dla niego marnowaniem czasu spędzanego w szkole. Inną konsekwencją obojętności na ucznia jest powtarzanie roku - dla niego to czas powtórzony (Groenwald 2019). Drugoroczność, postrzegana jako kara za niesprostanie wymaganiom edukacyjnym (Karpińska 1999; Lach 2003: 788), jest problemem nie tylko uczniów polskich (ok. 5\%), ale też innych państw, np. jej wskaźnik jest dość wysoki w szkołach podstawowych we Francji (17,8\%), w Portugalii i Holandii $(22,4 \%)$, natomiast na poziomie szkoły średniej sięga od 0,5\% w Finlandii do 31,9\% w Hiszpanii (Borodankova, Almeida Coutinho 2010: 61).

Mimo braku postępów w uczeniu się wynikających z zatrzymywania ucznia w czasie, mimo unicestwiania jego radości z uczenia się niekorzystne dla niego praktyki edukacyjne są kontynuowane. Znamienne jest w nich całkowite pomijanie głosu dziecka (Babicka-Wirkus, Groenwald 2018). Jego odczucia, próby buntu przeciwko zarządzaniu czasem uczenia się i zabawy albo są uciszane, albo w ogóle nie docierają do wychowawców, świadomie niedostrzegających tych prób. Zgodnie z ich oczekiwaniami uczeń ma być 
posłuszny, bierny, w milczeniu poddający się procesowi formowania go, zaś czas okazuje się w tym procesie jednym z przydatnych i niezwykle skutecznych narzędzi. Naznaczony $\mathrm{w}$ dzieciństwie piętnem temporalnej dyktatury, otrzymując w przyszłości zadanie do wykonania, uczeń nie będzie pytał: „po co?” je wykonać (o cel), lecz „na kiedy?”.

\section{Uczenie się (i nauczanie) w niewoli czasu}

W świetle paradygmatu obiektywistycznego czas jawi się jako uniwersalne narzędzie, które w despotyczny sposób jest wykorzystywane do zarządzania człowiekiem już od dzieciństwa. Temporalny charakter tego reżimu oddaje metafora współczesnej odmiany niewolnictwa, będącej w pewnych aspektach kontynuacją niewolnictwa rozumianego tradycyjnie, z takimi jego cechami, jak: cierpienie doświadczających zniewolenia czy wpisana w nie przemoc stanowiąca wręcz jego jądro (Stawiński 2005: 210; Bales 2019: 25). Obecnie do nowych technik zniewalania można dołączyć m.in.: a) poddawanie aktywności człowieka zaawansowanej technologicznie kontroli czasu i rozliczanie go z terminowości wykonanych zadań; b) zawłaszczanie pola jego wolności przede wszystkim w celu podnoszenia efektywności pracy (lub uczenia się); c) polityczne uwikłanie kierunków zmian oświatowych (Janowski 2000; Śliwerski 2015); d) biurokratyczne zarządzanie aktywnością. W opisie nowego niewolnictwa ludzi postrzega się jako instrumenty jednorazowego użytku, przydatne ze względu na wymierne korzyści dla kogoś (Bales 2019: 46, 70-71). W pewnym sensie znajduje ono odzwierciedlenie w transmisyjnym kształceniu, w którym po jednej stronie stają władający czasem na lekcji nauczyciele, po drugiej podporządkowani im i czasowi uczniowie. Choć stoją po dwu stronach, do walki między nimi nie dochodzi, dlatego że w istocie jednych i drugich cechuje bezwolność w uleganiu dyktaturze temporalnego ,nadzorcy”, wynikająca: a) z braku wyboru innych możliwości gospodarowania czasem (niewykluczone, że braku wiedzy o nich); b) ze znalezienia się w sytuacji bez wyjścia (Chyrowicz 2008) jako skutku uprzedmiotowienia i zniewolenia przez czas; c) z uzależnienia psychicznego od bycia nim zarządzanym. Zdaniem Kevina Balesa (2019: 329) istnieją narzędzia do wyzwolenia się z podporządkowania presji temporalności, ale sięgnięcie po nie utrudniają nierówny układ sił oraz brak woli i determinacji spętanych jej reżimem osób. W efekcie osoby te prezentują postawę bezradności wobec problemu, z którym nie potrafią sobie poradzić. Znamienne, że wszyscy, jakkolwiek uwikłani w nierówne relacje człowieka i czasu, wybierają bierność, a optując za zachowaniem status quo, wpisują się w stwierdzenie: „Niewola jest pasywnością” (Bierdiajew 2003: 53).

Według Balesa (2019: 181) wprowadzenie dyktatury czasu może wyrastać ze społecznego chaosu zrodzonego w strefie walki, gdzie narzucenie temporalnego rygoru staje się taktyką zaprowadzania porządku, ale też może się wywodzić z przestrzeni pustki, w której stare zasady są już martwe (lub nazwane ,martwymi”), a nowe dopiero mają wejść w życie. Stąd w celu zapewnienia złudnego poczucia stabilizacji ludziom bezwolnie jej oczekującym wprowadzane jest prawo normujące porządek społeczny. Zalicza się do niego 
również prawo oświatowe wraz z podstawowym dokumentem normującym kształcenie podstawą programową. Kryterium czasu jest jej istotnym elementem, jako że uczniowie i nauczyciele są rozliczani z terminowości wykonania określonych w niej zadań. Kiedy jednak z powodu rozlicznych uwarunkowań kontekstualnych dotrzymanie terminów okazuje się nierealne, wówczas podporządkowani edukacyjnym normom nauczyciele tworzą fikcyjną dokumentację (na użytek zwierzchników, ewaluacji zewnętrznej lub kontroli), wykazując pozorną zgodność nauczania z wymogami podstawy programowej. Są więc, podobnie jak uczniowie, niewolnikami czasu, a tym, co ich różni, jest inny status w hierarchii szkolnej społeczności (Mikiewicz 2016: 53). Pozwala im on m.in. na zarządzanie czasem uczenia się w skali mikro - w klasie, dozorowanie pracy uczniów oraz ocenianie (Niemierko 2002; Szyling 2015). W ocenianie dominujące obecnie w szkole wpisany jest pierwiastek czasu. Zawiera go: a) ocenianie kształtujące, które dotyczy kształcenia bieżącego, prowadzonego „tu i teraz”; b) ocenianie sumujące (sumatywne), polegające na sprawdzeniu, w jakim zakresie uczniowie sprostali wymaganiom programowym. Jest ono zatem rozliczeniem ucznia z edukacyjnej przeszłości. Osądza się go nie tylko za uczenie się, ale także za zachowanie, które powinno odpowiadać utrwalonym przez lata w tej dziedzinie normom społeczno-kulturowym (Sztompka 2002: 260-261). Zgodnie z nimi tradycyjnie zorientowani wychowawcy oczekują, że dziecko będzie posłuszne, milczące, pracowite (co brzmi jak charakterystyka niewolników). Z perspektywy tych wymogów typowe dla młodszych uczniów zachowania (ruchliwość, głośna radość, dziecięca fantazja itd.) zaczynają być traktowane w kategoriach dziecięcej niesubordynacji, która - zdaniem normatywnie ukierunkowanych nauczycieli - powinna podlegać karze nie tylko poprzez ocenianie; jedną z technik jej wymierzania jest jej przesunięcie w czasie w celu przedłużenia czasu trwania kary. Alice Miller przywołuje rozmowę z wychowawcą, który tak opisuje ten sposób dyscyplinowania dziecka: „Kiedy zasłużył sobie na karę, tylko odsuwam wykonanie wyroku na następny albo na trzeci dzień. Ma to dwie dobre strony: po pierwsze, mogę w tym czasie ochłonąc $\mathrm{z}$ gniewu i spokojnie rozważyć, jak mądrze postąpić w tej sprawie, a po drugie, mały delikwent przeżywa dziesięciokrotnie mocniej swoją karę nie tyle na własnym grzebiecie, ile musząc wciąż o niej myśleć" (Miller 1999: 45). Jakże odmienna od nauczycielskiej jest perspektywa doświadczenia tej kary przez ucznia. Opowiada o niej dziś dorosła już osoba, która wspomina sytuacje (nie były odosobnione), kiedy to nauczycielka, zwracając się do niej, mówiła: „Jutro sobie o tym (nieodpowiednim zachowaniu, nieodrobieniu pracy domowej itd.) porozmawiamy". Pamięta, że w tym momencie czas się dla niej zatrzymywał, zaczynała żyć w swoistym temporalnym zawieszeniu, w bezczasie (Barbour 2018: 535). Wciąż tylko myślała o tym, co będzie ,jutro", a bardzo chciała, by wymierzenie kary nastąpiło jak najszybciej. Czekała na nią. Oto przykład strategii pomagającej utrzymać dyscyplinę o iście niewolniczym rodowodzie. Choć dziecko doznaje krzywdy i przemocy, milczy i z pokorą przyjmuje karę „oczyszczającą” je z winy. Miller (1999: 124) dowodzi, że ludzie, którzy w dzieciństwie doświadczyli przemocy ze strony wychowawców, jako dorośli zastosują tę samą metodę zawladania, w istocie będącą ,jedynie pozornie troską o wychowywanych, 
W rzeczywistości [wychowujący] troszczą się jedynie o swą władzę. (...) [Ma ono na celu] gruntowne wszczepienie szacunku i lęku wobec władzy" (Filek 2001: 115). Z badań Magdaleny Grochowalskiej (2013) wynika, że zawładanie kształceniem następuje już na etapie edukacji przedszkolnej. W kolejnych latach nasila się, przyjmując formę tresury (Kopaczyńska 2013: 230-234).

\section{Ukryte strategie zawładania uczeniem się za pomocą czasu}

Co sprawia, że mimo nieustannego reformowania edukacji udaje się zachować ją w stanie niezmienionym? Jak to możliwe, że upływający czas, który z jednej strony wyznacza dynamikę przemian społeczno-kulturowych, z drugiej - nie odciska piętna na szkolnym kształceniu? W odpowiedzi przywołam zaledwie trzy strategie zawładania nauczaniem i uczeniem się przez czas; za wyborem przemawia ich wszechobecność w edukacyjnej codzienności, jak już wspomniałam, zdominowanej przez kształcenie normatywne i instrukcyjne.

\section{Uczenie się w okowach biurokratycznego zarządzania czasem}

W skali makro strategią kierowania czasem jest biurokratyczne nim zarządzanie. Z założenia funkcją biurokracji jest służebność, ale w kontekście edukacji nie służy ona uczniom i nauczycielom, lecz zarządzającym oświatą. Nieodległa historia pokazuje, że kolejne ekipy rządzące swoją obecność u władzy zaczynają od wprowadzenia zmian na stanowiskach urzędniczych. Stara biurokracja zostaje zastąpiona nową, ale jeszcze bardziej rozbudowaną, często wykorzystującą kadry dawnej biurokracji, gotową służyć każdemu porządkowi, każdej władzy. Również w przypadku edukacji następuje centralne sterowanie nią poprzez aparat biurokratyczny. Jest więc zarządzana przez urzędników, dla których znaczenie ma nie jej sens, ale rozliczalność z wykonania rozporządzeń oraz terminowość ich realizacji. Spełnienie tego wymogu nakłada na nauczycieli obowiązek planowania: kierunkowego, wynikowego i metodycznego. Niestety, za jego pomocą zamykają w sztywne ramy czasowe nie tylko dziecięce uczenie się, ale też sami godzą się na pozbawienie własnej pedagogicznej samodzielności (Bierdiajew 2003: 127).

Innym ważnym elementem zarządzania kształceniem przez czas jest niewyobrażalnie rozbudowana sprawozdawczość - rodzaj administracyjnie sterowanego kronikarskiego zapisu działań wykonanych w przeszłości, ponieważ to głównie ona jest rozliczana. Ze względu na nią przestrzeganie przepisów oświatowych oraz meldowanie o nich stają się ważniejsze niż realizacja celów kształcenia, a dokumentowanie nauczania jest istotniejsze niż realna praca z uczniem. Czas uczenia się dziecka opisany „na papierze” wykazuje spójność z tzw. papierowym wychowaniem, polegającym najpierw na opracowaniu statutu szkoły, ale już potem niesięganiu do niego, podobnie jak do innych dokumentów przechowywanych w przysłowiowej szufladzie biurka (Dudzikowa 2013: 425). W biurokratycznie zarządzanym kształceniu pozór i fikcja stają się jego istotnym elementem, o którym wszyscy wiedzą, lecz udają, że tej wiedzy nie posiadają (Frankfurt 2005). 


\section{Pozorowanie uczenia się podczas lekcji}

Pozór jest wskazywany jako skuteczna strategia umożliwiająca przetrwanie w niekorzystnym środowisku, stosowana nie tylko przez dzieci, ale też dorosłych oraz instytucje oświatowe (Lutyński 1990; Dudzikowa, Knasiecka-Falbierska (red.) 2013). Pojawia się więc w rozlicznych obszarach edukacyjnej codzienności. Podstawową fikcją jest nazywanie czasu spędzanego przez dziecko w szkole uczeniem się, ponieważ w istocie jest ono nauczane, a oczekuje się od niego jedynie posłuszeństwa w wykonywaniu poleceń nauczyciela i milczenia przez większość czasu na lekcji. Bywa więc, że autentyczne uczenie się, zamiast w szkole, odbywa się podczas korepetycji, zajęć pozalekcyjnych lub pozaszkolnych. Interesującym przypadkiem ucieczki przed szkolną rutyną czy nudą jest spędzanie czasu w sposób znacznie bardziej dla uczniów interesujący - na wagarach. Z jednej strony wagary są piętnowane $\mathrm{z}$ racji łamania statutu szkoły, jednak z drugiej stanowią świadectwo dysfunkcyjności edukacji. Co ciekawe, zdarza się, że uczniowie wychodzą na wagary po to, by z kolegami uczyć się w domu (Cylkowska-Nowak 2013).

Kolejnym przykładem ujawniającym marnowanie czasu uczenia się na lekcjach jest zastępowanie go uczeniem się w domu w ramach edukacji domowej, zyskującej popularność wśród rodziców gotowych osobiście przejąć odpowiedzialność za jakość uczenia się ich dzieci. To także dowód na malejące zaufanie do naznaczonego pozorem kształcenia instytucjonalnego (Budajczak 2004). Przykłady pozorowania uczenia się, czyli marnowania czasu spędzanego w szkole, można by mnożyć. Znamienne jest to, że mimo powszechności tego zjawiska wciąż wydaje się ono świadomie niedostrzegane.

\section{Czas uczenia się jako tabu}

Mechanizmem utrwalającym dyktaturę czasu w transmisyjnym kształceniu jest objęcie jej swoistą ,zmową milczenia”, rodzajem tabu, które zaślepiając, uniemożliwia skuteczne rozwiązanie tego problemu. Będąc niejawnym aspektem kształcenia, sprawia, że osoby poddane jej działaniu nie mają w ogóle świadomości jej istnienia, więc dzieci (i niektórzy nauczyciele) dostosowują się do niej bezwiednie. Bywa również, że przemilczanie problemu stosowania temporalnej przemocy wobec uczniów prowadzi do wypierania tego problemu ze społecznej świadomości, co w konsekwencji może prowadzić do jego eskalacji. Niedostrzeganie go w klasyfikacji Jacka Filka (2001: 163-166) przyjmuje formy: 1) „nieprzytomności” jako udawania niewiedzy o problemie; 2) „obojętności”, czyli dostrzegania trudności, lecz nieprzejmowania się nimi; 3) „bierności” jako niepodejmowania jakiegokolwiek działania na rzecz zmiany, a także przekonującego (samego siebie) usprawiedliwiania własnej postawy; 4) ,poczucia niewinności” za przemoc wobec czasu uczenia się dziecka, ponieważ jej źródła postrzega się poza swoją osobą.

Typowa dla paradygmatu obiektywistycznego anonimowość podejmujących edukacyjne decyzje oraz zarządzających czasem sprawia, że wszelkie nieprawidłowości w tym zakresie pozostają bezkarne, tym bardziej że towarzyszy im milczenie dorosłych, w którym dorównują milczeniu dzieci na lekcji. Tabuizacja tego problemu prowadzi do utrwalenia go i podtrzymania (Wasilewski 2010: 347-348). Staje się również środkiem wyrażania 
respektu wobec władzy, ale też formą jej niczym niezakłóconego istnienia. Przecież problem zniewalania uczenia się dzieci poprzez czas, jako objęty tabu, po prostu nie istnieje.

\section{Zakończenie}

Rozpatrywany w tym artykule czas w uczeniu się został zakotwiczony w transmisyjnie wymodelowanym nauczaniu i uczeniu się, z dominującymi w nim dwiema orientacjami temporalnymi: przeszłością, do której teraźniejszość się odwołuje i na której bazuje, oraz przyszłością - o tyle specyficzną, że planowaną dla dziecka przez dorosłych. A to oznacza, że będzie ono kiedyś żyło w świecie przez nich urządzonym i bardzo podobnym do aktualnie istniejącego. Stąd powszechne w tym kształceniu strategie temporalne naznaczają uczenie się zatrzymaniem w czasie, powtarzaniem go, a nawet marnowaniem. Mimo dowodów na nierozwojowe (antyrozwojowe) oddziaływanie czasu na uczenie się nie planuje się wprowadzenia zmian, przeciwnie - w celu zachowania edukacyjnego status quo przyjmuje się m.in. biurokratyczne zarządzanie czasem uczenia się (w skali makro), akceptuje strategie pozorowania fikcyjności uczenia się oraz przemilcza i nie dostrzega przemocowych oddziaływań na dziecko poprzez zniewalanie jego uczenia się wymogiem terminowości opanowania określonych kompetencji (zob. Szyling 2019). W efekcie czas staje się jeszcze jednym instrumentem symbolicznej przemocy.

Trzeba podkreślić, że czas w uczeniu się analizowanym z perspektywy obiektywistycznej, choć dominującej w polskich szkołach, nie jest jedyną opcją refleksji nad zagadnieniem temporalności w kształceniu. Są bowiem odmienne od obiektywistycznego podejścia paradygmatyczne: konstruktywistyczno-interpretatywne i transformatywne. Powiązane z nimi modele kształcenia ukazują odmienne postaci funkcjonowania czasu w dziecięcym uczeniu się. Otwierają one nie tylko nowe perspektywy w myśleniu o nim, ale też skłaniają do wsparcia dziecka w takim uczeniu się, w którym nie będzie odczuwało presji czasu.

\section{Literatura}

Babicka-Wirkus A., Groenwald M. (2018), Gtos dziecka w przedszkolu-między swoboda wypowiedzi a milczeniem. „Problemy Wczesnej Edukacji”, 1(40).

Bales K. (2019), Jednorazowi ludzie. Nowe niewolnictwo w gospodarce światowej. Gdańsk, Wydawnictwo w Podwórku.

Barbour J. (2018), Koniec czasu. Nowa rewolucja w fizyce. Kraków, Wydawnictwo Copernicus Center Press.

Bierdiajew M. (2003), Niewola i wolność człowieka. Zarys filozofii personalistycznej. Kęty, Wydawnictwo Antyk.

Borodankova O., Almeida Coutinho A.S. (2010), Drugoroczność w kształceniu obowiąkowym w Europie: regulacje i statystyki. Warszawa, Wydawnictwo Fundacja Rozwoju Systemu Edukacji. http://czytelnia.frse.org.pl/media/126PL.pdf, 12.12.2019. 
Bray M. (2012), Korepetycje. Cień rzucany przez szkoły. Warszawa, Wydawnictwo Wolters Kluwer Polska.

Budajczak M. (2004), Edukacja domowa. Gdańsk, Gdańskie Wydawnictwo Psychologiczne.

Chyrowicz B. (2008), O sytuacjach bez wyjśsia w etyce. Kraków, Wydawnictwo Znak.

Cylkowska-Nowak M. (2013), O nieszkodliwości wagarowania. Konsumpcyjne uwikłania ofiar i/lub sprawców pozoru w edukacji szkolnej. W: M. Dudzikowa, K. Knasiecka-Falbierska (red.), Sprawcy i/lub ofiary działań pozornych w edukacji szkolnej. Kraków, Oficyna Wydawnicza Impuls.

Dudzikowa M. (2013), Pozór w edukacji - diagnoza, próby rozwiązań. W: M. Dudzikowa, K. Knasiecka-Falbierska (red.), Sprawcy i/lub ofiary działań pozornych w edukacji szkolnej. Kraków, Oficyna Wydawnicza Impuls.

Dudzikowa M., Knasiecka-Falbierska K. (red.) (2013), Sprawcy i/lub ofiary działań pozornych w edukacji szkolnej. Kraków, Oficyna Wydawnicza Impuls.

Dzieliński K. (2017a), Czy lekcje powinny zaczynać się tak wcześnie? http://www.geekweek.pl/ aktualnosci/29034/czy-lekcje-powinny-zaczynac-sie-tak-wczesnie, 14.05.2017.

Dzieliński K. (2017b), Poranne zajęcia w szkole złe dla zdrowia. http://www.geekweek.pl/aktualnosci/31314/poranne-zajecia-w-szkole-zle-dla-zdrowia, 14.05.2017.

Filek J. (2001), Filozofia jako etyka. Kraków, Wydawnictwo Znak.

Frankfurt H.G. (2005), O wciskaniu kitu. Warszawa, Wydawnictwo Czuły Barbarzyńca.

Gagnè R.M., Briggs L.J., Wager W.W. (1992), Zasady projektowania dydaktycznego. Warszawa, Wydawnictwa Szkolne i Pedagogiczne.

Grochowalska M. (2013), Rzeczywisty czy (i) iluzoryczny obraz dyskursu edukacyjnego w przedszkolu. W: M. Dudzikowa, K. Knasiecka-Falbierska (red.), Sprawcy i/lub ofiary działań pozornych w edukacji szkolnej. Kraków, Oficyna Wydawnicza Impuls.

Groenwald M. (2019), Perspektywy czasu w edukacji geograficznej. Wybrane aspekty. W: J. Angiel, E. Szkurłat (red.), Miejsce i przestrzeń. Edukacja geograficzna w ujęciu humanistycznym. Poznań, Bogucki Wydawnictwo Naukowe.

Hawking S. (2015), Krótka historia czasu. Od wielkiego wybuchu do czarnych dziur. Poznań, Wydawnictwo Zysk i S-ka.

Janowski A. (2000), Do czego sktania nas świat. Tendencje oświatowe w krajach rozwiniętych. W: K. Kruszewski (red.), Pedagogika w pokoju nauczycielskim. Warszawa, Wydawnictwa Szkolne i Pedagogiczne.

Karpińska A. (1999), Drugoroczność. Pedagogiczne wyzwanie dla współczesności. Białystok, Wydawnictwo Uniwersyteckie TransHumana.

Klus-Stańska D. (2018), Paradygmaty dydaktyki. Myśleć teoria o praktyce. Warszawa, Wydawnictwo Naukowe PWN.

Kopaczyńska I. (2013), Podstawa programowa dla klas I-III szkoły podstawowej jako punkt wyjścia działań pozornych. W: M. Dudzikowa, K. Knasiecka-Falbierska (red.), Sprawcy i/lub ofiary działań pozornych w edukacji szkolnej. Kraków, Oficyna Wydawnicza Impuls.

Korzeniecka-Bondar A. (2018), Codzienny czas w szkole. Fenomenograficzne studium doświadczeń nauczycieli. Kraków, Oficyna Wydawnicza Impuls.

Kruszko K. (2006), Nauka domowa dzieci w wieku wczesnoszkolnym. Siedlce, Wydawnictwo Akademii Podlaskiej.

Lach J. (2003), Drugoroczność. W: T. Pilch (red.), Encyklopedia pedagogiczna XXI wieku. T. 1. Warszawa, Wydawnictwo Akademickie „Żak”. 
Lutyński J. (1990), Nauka i polskie problemy. Komentarz socjologa. Warszawa, Państwowy Instytut Wydawniczy.

Martyniuk W. (2012), Szkolny dzwonek - atrybut szkolnej codzienności. „Teraźniejszość - Człowiek - Edukacja", 3(59).

Mikiewicz P. (2016), Socjologia edukacji. Teorie, koncepcje, pojęcia. Warszawa, Wydawnictwo Naukowe PWN.

Miller A. (1999), Zniewolone dzieciństwo. Poznań, Wydawnictwo Media Rodzina.

Niemierko B. (1995), Cele kształcenia. W: K. Kruszewski (red.), Sztuka nauczania. Czynności nauczyciela. Warszawa, Wydawnictwo Naukowe PWN.

Niemierko B. (2002), Ocenianie szkolne bez tajemnic. Warszawa, Wydawnictwa Szkolne i Pedagogiczne.

Stawiński J. (2005), Niewolnictwo. W: G. Marshall (red.), Stownik socjologii i nauk społecznych. Warszawa, Wydawnictwo Naukowe PWN.

Szadura J. (2017), Czas jako kategoria językowo-kulturowa w polszczyźnie. Lublin, Wydawnictwo Uniwersytetu Marii Curie-Skłodowskiej.

Sztompka P. (2002), Socjologia. Analiza społeczeństwa. Kraków, Wydawnictwo Znak.

Szyling G. (2015), Uczniowskie poczucie sprawstwa a praktyki oceniania we wczesnej edukacji. „Studia Pedagogiczne”, 68.

Szyling G. (2019), Atrofia nieformalnej diagnostyki edukacyjnej we wczesnej edukacji. Między biernościa i przemoca poznawcza w epoce ekspertów. „Problemy Wczesnej Edukacji”, 4(47).

Śliwerski B. (2015), Edukacja w polityce. Polityka w edukacji. Inspiracje do badań polityki oświatowej. Kraków, Oficyna Wydawnicza Impuls.

Urry J. (2009), Socjologia mobilności. Warszawa, Wydawnictwo Naukowe PWN.

Wasilewski J.S. (2010), Tabu. Warszawa, Wydawnictwo Uniwersytetu Warszawskiego.

Wiśniewska-Kin M. (2013), Dominacja a wyzwolenie. Wczesnoszkolny dyskurs podręcznikowy i dziecięcy. Łódź, Wydawnictwo Uniwersytetu Łódzkiego. 